\title{
Why are Indigenous communities seeing so few cases of COVID-19?
}

\author{
Cite as: CMAJ 2020 August 24;192:E993-4. doi: 10.1503/cmaj.1095891
}

Posted on cmajnews.com on August 7, 2020.

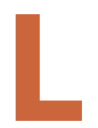
ike most people, Tania Cameron was watching the news intently as the first cases of coronavirus disease 2019 (COVID-19) were reported in Canada. A member of Niisaachewan First Nation and regional coordinator for Indigenous Sport and Wellness Ontario, she worried that no one was talking to Indigenous communities about the pandemic heading their way.

"When I called a couple of [personal protective equipment] supply companies, they told me, 'We're not allowed to announce it, but we're sold out and if we do get any, priority goes to the hospital.' So that to me was a warning," Cameron says. She texted friends in the community, chiefs and council members to raise the alarm and offer help updating pandemic plans.

It wasn't the first time Cameron has had to prepare for a public health crisis - she and a handful of local health directors developed her community's first pandemic plan in response to the 2002 outbreak of severe acute respiratory syndrome.

Then as now, many people feared that the virus could devastate communities already contending with the legacy of colonization - poverty, overcrowding, limited health infrastructure and poor access to clean water - ideal conditions for the spread of disease. But despite these challenges, Indigenous communities have fared better than the rest of Canada in the first wave of the COVID-19 pandemic.

As of Aug. 6, the percentage of people living on First Nations reserves who have tested positive for COVID-19 was one-quarter that of the general Canadian population. Of a total 422 cases of COVID-19 on reserves, more than $80 \%$ have recovered. Six people have died a fatality rate one-fifth that of the general population. According to Indigenous
Services Canada, "First Nations communities are flattening the curve."

British Columbia is a case in point the province reported just 90 cases of COVID-19 among First Nations people in the first six months of 2020. Health officials attributed these low numbers to the "extraordinary" public health measures taken by Indigenous communities.

According to Dr. Nel Weiman, acting deputy chief medical officer for the First Nations Health Authority, the memory of past epidemics in which entire villages were nearly wiped out made people especially cautious about COVID-19. "Communities recognized the need to really take this seriously and install their own versions of public health measures," says Weiman.

Indigenous people got creative to stay connected virtually, set up trailers for self- isolation, and made roadblocks to control access to their communities. Now, as the rest of the province has reopened, many of these communities are fighting to remain closed. "Some people find it controversial, but I don't think people can argue that by limiting access ... the communities have been able to keep themselves safe to a certain extent," says Weiman.

The First Nations Health Authority also put out special public health messages specifically recognizing Indigenous strengths and the sacrifices made by communities during the lockdown. Many have put on hold or modified ceremonies, funerals, and rites of passage.

Robert Bonspiel, director of First Nations Paramedics, the only Indigenous private ambulance service in Quebec, attributes low infection rates among

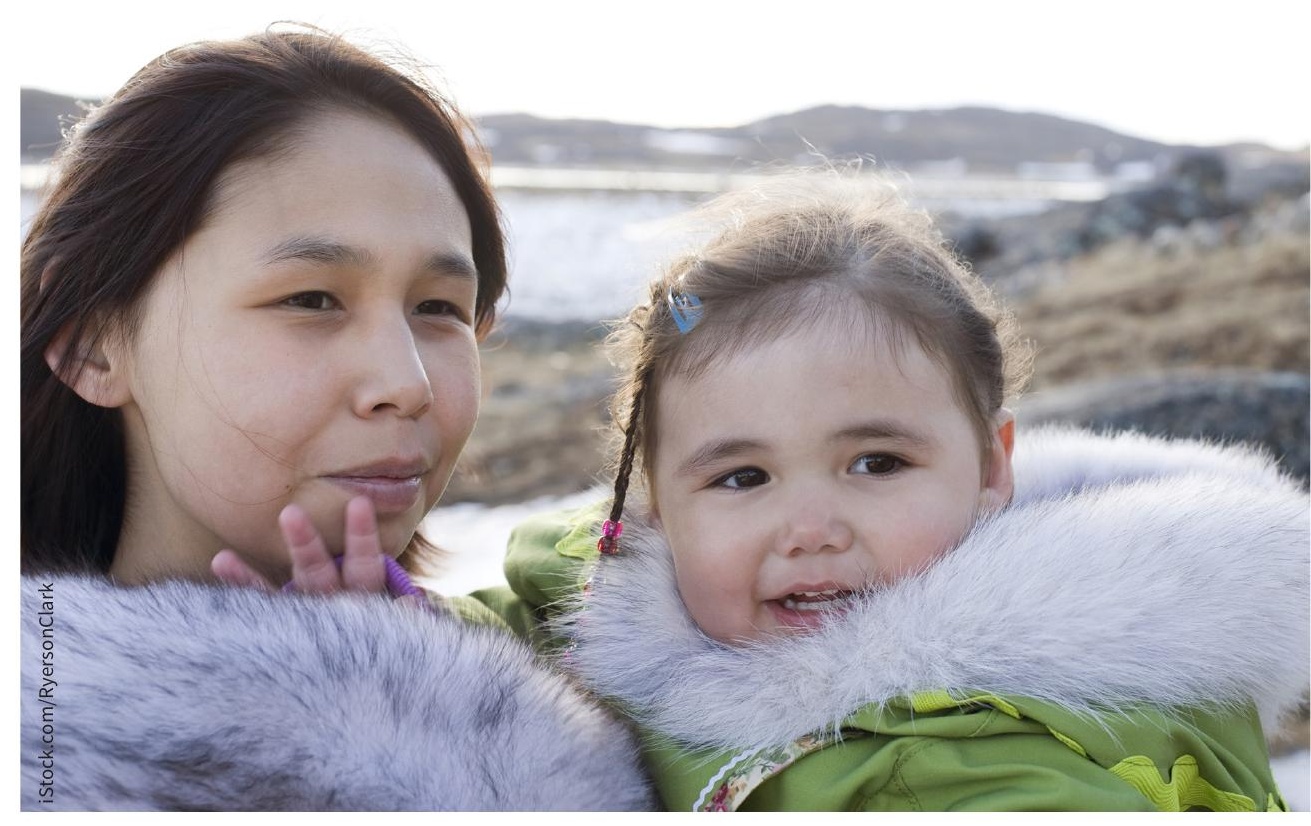

Indigenous communities have fared better than the rest of Canada in the first wave of the pandemic despite facing major challenges to infectious disease control. 
Indigenous people to communities taking a proactive approach to the pandemic.

As codirector of the emergency response unit for the Mohawk community of Kanehsatà:ke, Quebec, "we asked people to go back to their roots, to go back to the way it was years ago, to be caring about their neighbours like their family," he says.

In addition to setting up roadblocks like in $B C$, the community encouraged people to stay at home by delivering food hampers, prescriptions, and meals for Elders. Keeping Elders at home may have been protective, given the high number of deaths in long-term care, Bonspiel adds. "If you look at the general Quebec population, their Elders are placed [in nursing homes.] In the Mohawk community, and First Nations communities, we don't do that."
For Inuit in Canada, fighting tuberculosis (TB) has prepared communities for COVID19. "Inuit communities, unfortunately, have become adept at contact tracing and isolation for TB," so pandemic measures were "not a new phenomenon," says Deborah Van Dyk, senior policy director with Inuit Tapiriit Kanatami, the nonprofit representing over 60000 Inuit in Canada.

"Strengths-based" strategies to mobilize communities, reduce poverty and implement Inuit-specific solutions to eliminate TB may also support the response to COVID-19, Van Dyk says. Inuit communities have also been working on building up their public health staff, "so it was a lot easier for that kind of staff to redeploy."

Van Dyk says shutting down travel quickly may have helped to prevent the spread of COVID-19 among Inuit people, but it's still too early to say without any evaluations of the public health response. Meanwhile, "there is still a lot of work to be done in terms of impact ... around mental health, around businesses, education and that kind of thing," she says.

Courtney Skye, a research fellow at the Yellowhead Institute, a First Nationsled think tank, cautions that COVID-19 data are not being collected in a granular way that would show which Indigenous communities are affected at what rates. Without those data, "we lose the ability to hold decision-makers responsible for the actions that they're taking on behalf of the community."

Jolene Banning, Fort William First Nation, Ont. 